\title{
Sport promotion and sales management
}

\author{
Zahra Aminiroshan $^{\mathrm{a}^{*}}$, Esmaiel Sharifian $^{\mathrm{b}}$ and Seyed Mostafa Siyadat ${ }^{\mathrm{a}}$
}

${ }^{a}$ M.Sc of sport management

${ }^{b}$ Shahid Bahonar University of Kerman, Kerman, Iran

C H R O N I C L E

\begin{tabular}{l}
\hline Article history: \\
Received December 28, 2013 \\
Accepted 4 May 2014 \\
Available online \\
May 10 2014 \\
\hline Keywords: \\
Advertising \\
Sale promotion \\
Product sector \\
Sport industry
\end{tabular}

\section{Introduction}

During the past few years, the world of sport has been experiencing new marketing techniques to introduce products and services. Ratten and Ratten (2011) believed there are several opportunities on international sport marketing that combine various areas of marketing together with the sport marketing and international business literature. Besides, there is enormous potential for linking the sports marketing and international business literature through concentrating on entrepreneurial sport ventures, appear worldwide. For the past several years, professional sport business units have started to shift from cost-based ticket pricing strategies to a demand-based model, where price considerations

\footnotetext{
*Corresponding author

E-mail addresses: z.aminiroshan@yahoo.com (Z. Aminiroshan)

\begin{abstract}
At the beginning of third millennium, the world of sport has been experiencing new marketing techniques to introduce products and services. The purpose of this study was to compare advertising and sales promotion strategies, the effects of different strategies in sport production companies to retain or to gain market share among selected firms, which were active in Iran. The method of survey was descriptive - analytical and some questionnaires were used for collecting data in Likert scale. The validity of the questionnaire were estimated by interview with professors and exports in marketing and sport marketing and the reliability was assessed by using Cronbach's alpha $(\alpha=0.89)$. Statistical population of the study includes Sport GoodsProducing companies in Iran $(\mathrm{N}=180)$ and 122 firms formed the study sample. For testing the hypothesis, we have used Paired Samples T-Test. The analysis of findings showed that there was a meaningful difference between using advertising and sales promotion strategies. In general, we can say, there are some limited applications of using techniques and methods of sales promotion strategies in Iranian sport industry and methods of advertising. Consequently, regarding the intense competition among companies as well as fast growth of markets and fast changes in consumer's behavior, identifying the best methods for corresponding relationship to customer would be required.
\end{abstract}


were driven, in part, by market demand. Shapiro and Drayer (2013), for instance, investigated Dynamic ticket pricing (DTP), where prices change on daily bases according to several market factors. The motivation for DTP stems from the substantial growth of the secondary ticket market, where ticket prices were almost completely demand driven. They examined price determinants in the primary market where DTP was implemented and comparable tickets in the secondary market.

There are several new facilities such as social web pages, satellite dishes, etc. where people are introduced with various kinds of sport facilities (Aminuddin \& Parilah, 2008). In such circumstances, some people may become interested in purchasing a sport-based product based on sales promotions and others may become interested in a particular product simply by watching advertisement. Therefore, it is essential to learn more about the effects of various promotion techniques for better marketing planning (Irwin, 2002). A challenge with advertising communications is to fully understand beliefs driving people's behavior toward advertising. Successful implementation of sport communication needs a better understanding of the beliefs composing behaviors toward advertising through sport.

James (2009) performed a 4-phase study to develop a scale measuring 7 belief dimensions as indicants of attitude toward advertising through sport. During the first phase, the study applied an initial test of the proposed instrument and within the next stage; the study evaluated the revised scale based on internal-consistency tests and exploratory factor analysis. Next, the scale's reliability and validity were verified using confirmatory factor analysis and finally, the study re-examined the internal consistency and factor structure of the scale. The combined results provided some support for the conceptualization and measurement of the belief dimensions for future study of the relationships between beliefs about and attitude towards advertising through sport.

Deng (2009) in a survey concentrated more about family function especially in Asian countries, which emphasize significantly on family, which can provide caring emotional communication. Therefore, from both strong-willed hero worship and water-like fork environment, consumers are believed to be able to easily link well-known Sport firms like Nike's image with not only strength, but also warmth. They may use some preferred media such as TV, specific magazines, outdoor and internet to promote their products and services.

Park et al. (2008) examined a theory of persuasion for PSAs designed to lead people to assist with the Special Olympics. They used broaden the Elaboration Likelihood Model (ELM) by incorporating a newly added personality variable, empathic tendency, and demonstrated how this variable influences on audiences' information processing of PSAs. In order to examine the ELM, a three-way factorial design was applied and their results indicated that both high empathy subjects and low empathy subjects were highly motivated to process the persuasive messages, implying that both groups followed the central route to processing.

Tsiotsou and Alexandris (2009) proposed a model in which fans' team attachment was the determinant of three sponsorship outcomes including sponsor image, purchase intentions, and word of mouth. They also examined the role of sport fans' involvement on the development of team attachment. Their findings supported the premise that highly attached fans tend to develop positive image for their team sponsor, exhibit higher intentions for buying and suggesting the sponsor's products.

Liu et al. (2009) investigated the relationships between attractiveness of athlete endorsers, match-up, and consumers' buying intention embedded in the China context. They reported that no matter whether the attractiveness was high, middle, or low, the high endorser-product match-up might produce higher purchase intention than the low endorser-product match-up could. In addition, the purchase intention created by the high-attractive endorser with low match-up could be bigger than that generated by low-attractive endorser with high match-up. Lee and Ferreira (2013) investigated the direct and moderating effects of team identification and cause firms' identification on consumer 
behavior toward cause related sport marketing (CRSM) programs based on intercollegiate sport contexts in the United States. In their survey, fit between a sport team and a cause yielded a bigger effect on behaviors when consumer affinity toward the sport team was more positive. However, fit maintained little or no effect when consumer affinity toward the cause was positive, but it played a substantial and positive role when consumers stated low affinity toward the cause.

\section{The proposed method}

The purpose of this study was to compare advertising and sales promotion strategies, the effects of different strategies in sport production companies to retain or gain market share among selected firms, which were active in Iran. The method of survey was descriptive - analytical and some questionnaires are used for collecting data in Likert scale. The validity of the questionnaire were estimated by interview with professors and exports in marketing and sport marketing and the reliability was assessed by using Cronbach's alpha $(\alpha=0.89)$. Statistical population of the study includes Sport Goods-Producing companies in Iran $(\mathrm{N}=180)$ and 122 firms formed the study sample. For testing the hypothesis, we have used Paired Samples T-Test. Table 1 demonstrates the results of the survey.

\section{Table 1}

The summary of testing the difference between two groups of advertisement and sales promotion

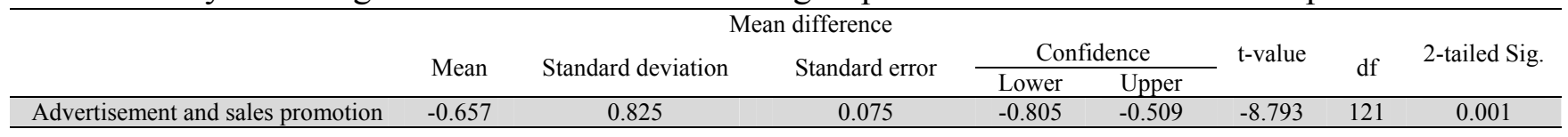

The results of Table 1 show that there was a meaningful difference between using advertising and sales promotion strategies. In general, we can say, there are some limited applications of using techniques and methods of sales promotion strategies in Iranian sport industry and methods of advertising. Consequently, regarding the intense competition among companies and fast growth of markets and fast changes in consumer's behavior, identifying the best methods for corresponding relationship to customer would be required.

\section{Conclusion}

In this paper, we have presented an empirical investigation to study the difference between using advertisement techniques and sales promotion strategies. The findings of this survey have indicated that there were some limited applications of using techniques and methods of sales promotion strategies in Iranian sport industry and methods of advertising. The results of this survey are consistent with other researchers' findings such as Tsiotsou and Alexandris (2009), Ratten and Ratten (2011) and Irwin et al. (2002).

\section{Acknowledgement}

The authors would like to thank the anonymous referees for constructive comments on earlier version of this paper.

\section{References}

Aminuddin, Y., \& Parilah, M. S. (2008). Globalization and the Malaysian sports industry. Research Journal of International Studies, 8, 112-116.

Deng, T. (2009). "Just Done It"---Nike's New Advertising Plan Facing Global Economic Crisis. International Journal of Business and Management, 4(3), 102. 
Irwin, R. L., Sutton, W. A., \& McCarthy, L. M. (2002). Sport promotion and sales management. Human Kinetics.

James, J. D. (2009). Enhancing advertising communications: Developing a model of beliefs about advertising through sport. International Journal of Sport Communication, 2(1), 1-20.

Lee, J., \& Ferreira, M. (2013). A role of team and organizational identification in the success of cause-related sport marketing. Sport Management Review,16(2), 161-172.

Liu, M. T., Huang, Y. Y., \& Minghua, J. (2007). Relations among attractiveness of endorsers, matchup, and purchase intention in sport marketing in China. Journal of Consumer Marketing, 24(6), 358-365.

Park, M., Turner, B. A., \& Pastore, D. L. (2008). Effective public service advertisements to attract volunteers for the special Olympics: An elaboration likelihood perspective. Sport Management Review, 11(2), 165-192.

Ratten, V., \& Ratten, H. (2011). International sport marketing: practical and future research implications. Journal of Business \& Industrial Marketing, 26(8), 614-620.

Shapiro, S. L., \& Drayer, J. (2013). An examination of dynamic ticket pricing and secondary market price determinants in Major League Baseball. Sport Management Review, 17(2), 145-159.

Tsiotsou, R., \& Alexandris, K. (2009). Delineating the outcomes of sponsorship: sponsor image, word of mouth, and purchase intentions. International Journal of Retail \& Distribution Management, 37(4), 358-369. 